\title{
Daily News and the Construction of Time in Late Stuart England, 1695-1714
}

\section{Tony Claydon}

\begin{abstract}
Recent scholarship has suggested that frequent receipt of news, especially in new media such as newspapers, altered conceptions of time in the early modern period. In particular, a new and modern "present" was born. This occupied a halfknown and semifluid point between the fixity of the past and the unpredictability of the future. It created an imagined contemporaneous moment that linked geographically dispersed events. It was progressive, appearing to move the world ever forward into a novel state. However, close examination of English newspapers in the period 16951713 , the first era of sustained news periodicals, calls these suggestions into question. Certainly the press of this era provided a constant and corrective update of information from all over Europe. This might have encouraged a sense of a fluid, contemporaneous, and progressive present. However, newspapers also tended to catalog information like a chronicle, which had the potential to fix contents as established history rather than fluid news. Delays in communication from distant places and journalistic practices of holding back stories for later publication ensured that information of different ages was presented on the same page. This destroyed any clear sense of a contemporaneous moment. The requirement to print the next issue even when there was no new information drew explicit attention to the lack of progressive development in some stories. This article posits a highly fractured presentation of time in later Stuart newspapers. It suggests that this is perhaps best analyzed by concepts drawn from "postmodern" theory rather than a hunt for emerging features of "modernity."
\end{abstract}

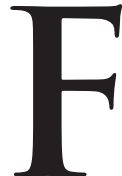

or some decades, the Stuart age in England has been analyzed as the crucible of a new print-centered culture. With the rapid expansion of the press over the seventeenth century, scholars have posited new models of information and new kinds of social action made possible by these models. It has been suggested that in comparison with their predecessors, subjects of the later Stuart monarchs were significantly better informed about their world, and thus were able to participate in political, religious, and cultural debates that had hitherto been steered by elites. Jürgen Habermas's notion of a "structural transformation of the public sphere" has been central here, making an argument for a newly active audience

Tony Claydon studied at Oxford and University College London before being appointed to a postdoctoral fellowship at Fitzwilliam College Cambridge and then a lectureship at Bangor University in North Wales. At Bangor he has served as professor of early modern history; head of the School of History, Welsh History, and Archaeology; director of the Institute of Medieval and Early Modern Studies at the Universities of Aberystwyth and Bangor; and head of the College of Arts and Humanities. He is author of several books and numerous articles on the political and religious culture of later Stuart England. The author would like to thank Hannah Barker, Vyvian Evans, Jeremy Gregory, and the readers and editors of this journal for comments on earlier drafts of this article. 
that could be critical of those in authority. This, however, has not been the only model of press-induced change, and many historians have argued for brave new worlds without accepting Habermas's position in its entirety. ${ }^{1}$

Some readings of print in the seventeenth century have concentrated on perceptions of time as much as political culture. C. John Sommerville has argued that periodic receipt of news via print created a progressive expectation in audiences. People began to anticipate that stories would develop steadily over time with successive installments. New reports constantly superseded previous ones, so that the latest information was always more important than what had gone before. Sommerville claims that these features of regular news undermined static assumptions about the world and by extension destroyed conservative philosophies. ${ }^{2}$ Daniel Woolf, meanwhile, has suggested that regular updates created a new category in temporal understanding. ${ }^{3}$ Hitherto, events had either belonged to an unknowable future or to a certain past. With the advent of constantly arriving news, whose truth was not always fully established, the modern "present" was born. This new time was filled with semifluid events. It was felt to be partly fixed by supposedly known facts but also potentially alterable by its own forward momentum, by receipt of more accurate information, by reconstruction as audiences made sense of incoming material, or by rapid action in response to arriving data. Other scholars have highlighted a third aspect of a news-related change in time perception. Pushing back a concept crucial to Benedict Anderson's analysis of "imagined communities" in the early nineteenth century, scholars led by Brendan Dooley have explored an early modern "contemporaneity," suggesting that a steady flow of information extended current experience beyond immediate circumstances. ${ }^{4}$ It produced a community-building sense of participation in widely dispersed occurrences well before the birth of telephones and wireless that Anderson argued had been responsible for this change. ${ }^{5}$ According to this view, a new and more modern "present" was constructed by the advent of dense and regular news. This present was progressive, it was neither the solidified chronicle of history nor the untestable speculation of prophecy, and it linked people in geographically separate locations.

As we shall see, these suggestions fit much of the evidence. They also parallel arguments in other disciplines that have considered the constructions of time. For example, there are psychological approaches to temporal perception suggesting

\footnotetext{
${ }^{1}$ Jürgen Habermas, The Structural Transformation of the Public Sphere, trans. Thomas Burger and Frederick Lawrence (Cambridge, MA, 1989). For some discussion of the use of the "public sphere" in late Stuart historiography, see Brian Cowan, "Geoffrey Holmes and the Public Sphere: Augustan Historiography from Post-Namierite to Post-Habermasian," Parliamentary History 28, no.1 (February 2009): 166-78.

${ }^{2}$ C. John Sommerville, The News Revolution in England: Cultural Dynamics of Daily Information (Oxford, 1996), esp. 10-13.

${ }^{3}$ Daniel Woolf, "News, History, and the Construction of the Present in Early Modern England," in The Politics of Information in Early Modern Europe, ed. Brendan Dooley and Sabrina A. Baron (London, 2002), 80-118.

${ }^{4}$ Benedict Anderson, Imagined Communities: Reflections on Origin and Spread of Nationalism, rev. ed. (London, 1991), 24.

5 Brendan Dooley, ed., The Dissemination of News and the Emergence of Contemporaneity in Early Modern Europe (Farnham, 2010); for the older view, see Stephen Kern, The Culture of Time and Space, 1880-1918 (Cambridge, MA, 1993), 63-80; Barbara Adam, Timewatch: The Social Analysis of Time (Cambridge, 1995), chap. 5.
} 
that a density of novel sense data creates and prolongs awareness of the present by forcing self-conscious reflection on immediate events. ${ }^{6}$ Similarly, some accounts of the rise of the novel in the early eighteenth century see the emergence of a new genre based on a new understanding of present time. This innovative form of fiction borrowed textual forms from news media and was centered on the experience of a closely described current moment whose meaning was under construction through the actions of individual characters. ${ }^{7}$ Again, some scholars have posited that-some time after the Middle Ages-a shift occurred in conceptions of chronology, from time being "full" - that is, structured by an overarching divine purpose and measured against the religious rituals that celebrated this— to time being "empty," an abstractly measured void to be filled by human action. This latter understanding focused attention on sequential, individual events, rather than the telos of any overall narrative. It was supported as well by the wider ownership of clocks and watches, greater attention to the supposedly efficient use of time, and the rise of diurnal literary forms such as the diary, travel journal, and, once again, the newspaper. ${ }^{8}$

Yet for all the promise of these ideas, a close study of journalism during the first great flowering of the press in the seventeenth century may make us pause. In the twenty or so years after the 1695 lapse of censorship, we see regular and dense news coverage. The period was marked by an expansion in the number of titles that lasted more than a few issues and the advent of dailies in 1702. Newspapers provided progressive narratives of near-contemporary events-publishing regularly, they were able to keep readers abreast of recently occurring developments as information reached them-and they supplied constantly updated stories that refined and replaced earlier reports. Yet the press had other features less familiar to twentyfirst-century readers. These structured information in ways that do not fit recent interpretations so neatly. As we shall see, newspapers could repeat material so that they froze rather than advanced narrative. They might fracture the present into different geographically dispersed moments. They might present current events in the form of fixed chronicles, rather than as evolving stories. We need to explore these features, or we may conclude that early modern constructions of time were closer to those of the twenty-first century than they actually were. Late Stuart conditions were often far removed from the constant news culture that has surrounded us for some decades and that may be influencing how we (mis)understand the past.

\section{口n}

\footnotetext{
${ }^{6}$ See, for example, George Herbert Mead, The Philosophy of the Present (Chicago, 1932), and Mind, Self and Society (Chicago, 1934); Robert E. Ornstein, On the Experience of Time (Baltimore, 1969); Michael G. Flaherty, A Watched Pot: How We Experience Time (New York, 1999).

${ }^{7}$ Ian Watt, The Rise of the Novel (London, 1957); Lennard J. Davis, Factual Fictions: The Origins of the English Novel (New York, 1983); J. Paul Hunter, Before Novels: The Cultural Contexts of Eighteenth-Century English Fiction (New York, 1990).

${ }^{8}$ Among works to advance versions of this idea are Anderson, Imagined Communities; Michel Foucault, Discipline and Punish: The Birth of the Prison, trans. Alan Sheridan (New York, 1977); Jacques Le Goff, "Labor, Time, and the Crisis of the Fourteenth Century," in Time, Work and Culture in the Middle Ages, trans. Arthur Goldhammer (Chicago, 1977), 43-52; E. P. Thompson, "Time, Work Discipline, and Industrial Capitalism," Past and Present 38, no.1 (January 1967): 56-97; Stuart Sherman, Telling Time: Clocks, Diaries, and the English Diurnal Form, 1660-1785 (Chicago, 1996).
} 
We should start with a brief justification for concentrating on English newspaper output in the years after 1695 . We will focus on this period not because regular news was entirely novel then, but because the frequency, regularity, and density of reporting increased considerably and permanently. News, of course, had always circulated in forms such as speeches, sermons, gossip, and letters, but the development of printed pamphlets and broadsides in the Tudor era increased the flow. By the early Stuart period, regular printed accounts of recent events on the Continent, called "corantos," were circulating, and manuscript newsletters penned by scribes retained by provincial gentry were flowing from London. The civil war years saw the emergence of "newsbook" periodicals in various forms, and from 1665 the London Gazette became the first long-standing publication to resemble modern newspapers: it appeared twice weekly, covered two sides of print in two columns of reports from across Europe, and ended with classified advertisements. 9 Such forms of news predate the period we will concentrate upon and persisted into the early eighteenth century. News naturally continued to spread orally after 1695, though word of mouth increasingly interacted with printed forms. Letter writing became something of an art form in the eighteenth century. A series of political disputes turned Queen Anne's reign into a golden age of the pamphlet and sermon. ${ }^{10}$ Perhaps more surprisingly, manuscript newsletters continued to thrive after 1695. Using the same mail delivery services as the new journals, they could sometimes compete with print for speed, and they found a wide audience when read aloud in such public places as coffeehouses. In some ways they perhaps even had advantages over newspapers. They could also be tailored more precisely for an individual audience, and as Alex Barber has found, they could have better penetration of the provinces or unique sources of information such as accounts of parliamentary debates. ${ }^{11}$

Yet for all their vigor, pre-1695 forms of media had limitations. They lacked the regular, consistent, and speedy communication of information that emerged in the newspapers of the last Stuart decades. It is true that nonprint news spread rapidly

\footnotetext{
${ }^{9}$ A good short overview of the press in the seventeenth century is provided by Bob Harris, Politics and the Rise of the Press, 1620-1800 (London, 1996), chap.1. Useful reflections on the nature of early news products can be found in Joad Raymond, The Invention of the Newspaper (Oxford, 1996). The most comprehensive collection of early English newspapers is the Burney Collection at the British Library, available to subscribers online via Gale Cengage Learning.

${ }^{10}$ Among a huge literature that supports this, see Adam Fox, Oral and Literate Culture in England, 1500-1700 (Oxford, 2000), chap. 7; Mark Knights, Representation and Misrepresentation in Later Stuart Britain: Partisanship and Political Culture (Oxford, 2005), chap. 5; Jonathan Barry, "Communicating with Authority: The Uses of Script, Print and Speech in Bristol, 1640-1714," in The Uses of Script and Print, 1300-1700, ed. Julia Crick and Alexandra Walsham (Cambridge, 2004), 191-208; Susan E. Whyman, The Pen and the People: English Letter Writers, 1660-1800 (Oxford, 2009); J. A. Downie, Robert Harley and the Press: Propaganda and Public Opinion in the Age of Swift and Defoe (Cambridge, 1979); Tony Claydon, "The Sermon, the Public Sphere and the Political Culture of Late SeventeenthCentury England," in The English Sermon Revised, ed. Lori Anne Ferrell and Peter McCullough (Manchester, 2000), 208-34. The London Gazette is still with us: www.london-gazette.co.uk.

${ }^{11}$ See the list of late Stuart newsletters compiled by Mark Knights and printed in The Entring Book of Roger Morrice, 1677-1691, 6 vols., ed. Mark Goldie, John Spurr, Tim Harris, Stephen Taylor, Mark Knights, and Jason McElligott (Woodbridge, 2007), 1:567-69; the comments on public reading in that work at 1:127; and the tailoring to the North Welsh gentry in the Mostyn Newsletters kept at Bangor, referred to me by Samuel Garland. Alex Barber's forthcoming "The Communication of Sin": The War for Free Expression, 1695-1715 (Woodbridge, 2012) will have full consideration of later newsletters.
} 
and effectively by word of mouth. Rumor raced through neighbourhoods, and sometimes community leaders served as local broadcasters (e.g., Thomas Cotton read manuscript newsletters aloud to neighbors in 1630s Colchester). ${ }^{12}$ However, the initial audience for speech and handwriting was smaller than for printed material, and the older media lacked newspapers' organized distribution and their guarantee that stories would not be altered in the telling. Meanwhile, among genres of printed works, nonperiodicals could not provide regular and predictable updates. Newspapers did exist in the Restoration era, but the legal framework under which publishers had to operate before William III's reign discouraged journalism. Except in periods of political dislocation-which, though important, were relatively short-printed material was subject to systems of prepublication censorship. Obeying the rules meant delay and possible external editing. These were severe handicaps for newspapers, whose speed and comprehensiveness were major selling points. Evading the rules was relatively easy for publishers of individual works, but this was more problematic for periodicals because they required a regular production process, which authorities had a better chance of detecting. As a result, newspaper coverage was thin until 1695, at which point political problems with the appointment of censors persuaded Parliament to allow prepublication supervision to lapse. ${ }^{13}$ Before this, the government-controlled London Gazette was only really challenged by other titles at times of political turmoil when legislation was unenforceable or went unrenewed. ${ }^{14}$

After 1695, by contrast, the newspaper press expanded at an astonishing rate. Within a year, three thrice-weekly titles were competing with the Gazette. The Flying Post, the Post Man, and the Post Boy were published on Tuesdays, Thursdays, and Saturdays. ${ }^{15}$ These were the days the mail left London for the provinces: appearing on these mornings ensured a wide and rapid circulation. The works differed in their political sympathies - the Flying Post, for example, was Whiggish and the Post Boy, Tory-so they sometimes gave prominence to rather different stories. Coverage was soon extended further as the three new titles were joined by a growing number of other newspapers. The date 11 March 1702 saw the first appearance of the Daily Courant. As its name hints, this was the first paper to appear every day, except Sundays.

Precise quantification of this press explosion runs into difficulties of definition. What exactly should we count as a newspaper, considering that some publications reported current affairs but appeared once a month or less, while others were confined to narrow topics such as agricultural prices, parliamentary votes, or stock movements? ${ }^{16}$ If we restrict ourselves to productions appearing at least once a week and containing a

${ }^{12}$ Cited by Harris, Politics, 7.

13 The best account is R. Astbury, "The Renewal of the Licensing Act in 1693 and Its Lapse in 1695," Library 5, no. 33 (December 1978): 296-322.

${ }^{14}$ Official control was weak during the civil wars (1640-49); licensing legislation lapsed during the exclusion crisis (1678-83) and the Glorious Revolution (1688-89).

15 The Flying Post began publication on 7 May 1695; the Post Boy on 17 May 1695. The Post Man first appeared under that title on 24 October 1695, though it had had a preexistence as "An Account of the Publick Transactions of Christendom" and other title variants since autumn 1694. It therefore fit the pattern of sporadic publication until 1695.

${ }^{16}$ See such 1690s publications as the monthly Present State of Europe; or the specialist press such as The Collection for the Improvement of Husbandry and Trade, The Course of the Exchange, or The Votes of the House of Commons. 
reasonably broad mix of information, exclude foreign language productions printed in England (the London Gazette also appeared as the Gazette de Londres), and use Carolyn Nelson and Mathew Seccombe's catalog of British newspapers to aid the calculation, we arrive at the following figures for sample months in the 1690s. ${ }^{17}$ In March 1692, seventeen newspaper issues appeared, dominated by nine from the London Gazette. By March 1696, this had risen to fifty-nine issues, with the Flying Post, the Post Man, and the Post Boy having thirteen or fourteen copies each, and by March 1700 the figure was up to seventy-seven. This number was soon to rocket further with the over twenty-five issues per month of the Daily Courant and the advent of a variety of other papers in the early years of Queen Anne.

This level of activity represented a significantly denser and more sustained production of news than had ever occurred before. It far outstripped the 1640s when some, usually only weekly, news periodicals had established themselves, and it lasted far longer than the temporary spike in printing during the exclusion crisis. As Mark Knights has argued, 1695 was a watershed and a key stage in the emergence of a new kind of "print culture."18 So if we want to test whether regular news constructed a different kind of time, the later Stuart period in England is the best proving ground. This is true even if some features of the world we will be exploring had emerged in some earlier moments of press freedom and even though scholars are correct to warn that we can exaggerate the novelty of William's and Anne's reigns. ${ }^{19}$ In what follows, we will look at the rich and sustained record of the newspapers between 1695 and 1713 (the latter year makes a convenient terminus since it saw the end of a major news story in the War of Spanish Succession). We will concentrate in particular on the period after the birth of the Daily Courant and give prominence to that paper in particular. This is partly because the Courant's more frequent appearance ramped up the overall number of issues and partly because it embodied the kind of closely spaced updating whose effects we wish to analyze. It is also, however, because the journal was so typical of the newspapers of its day. In the period we are studying, periodicals that concentrated on conveying facts, including the Courant, were remarkably similar in format and in assumptions about how to present data. A shared set of practices, one we shall describe and explore, defined the newspaper genre and gave a very particular flavor to the later Stuart culture of information. ${ }^{20}$

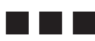

An initial survey of the press in our two decades provides some support for the idea of a new kind of present in the early modern world. Most important, it demonstrates

\footnotetext{
${ }^{17}$ Carolyn Nelson and Matthew Seccombe, eds., British Newspapers and Periodicals, 1641-1700: A Short Title Catalogue (New York, 1987).

${ }^{18}$ Knights, Representation and Misrepresentation, 227-28.

${ }_{19}$ Works exploring news culture before 1695 include Jason Peacey, "Print Culture and Political Lobbying during the English Civil Wars," Parliamentary History 26, no.l (Spring 2007): 30-48; Jason McElligott, Royalism, Print and Censorship in Revolutionary England (Woodbridge, 2007); Joad Raymond, ed., News, Newspapers and Society in Early Modern Britain (London, 1999); Ian Atherton, "The Press and Popular Political Opinion," in A Companion to Stuart Britain, ed. Barry Coward (Oxford, 2003), 88110; and other works by these author and editors.

${ }^{20}$ The features of newspapers described in this article were closely shared by the British Mercury, Daily Courant, English Post, Evening Post, Flying Post, London Gazette, Post Boy, Post Man, and Supplement.
} 
the kind of unfolding of reports over days, or even weeks, that would be central to a progressive and fluidly developing sense of time. Once papers appeared frequently, they could give regular and predictable updates on stories occurring over an extended period. For example, Marlborough's heroic march through Germany to the Danube in the summer of 1704 was breathtakingly rapid by the standards of early modern military maneuvers. Yet it nevertheless took some weeks to accomplish and was followed throughout by the press. On 1 June, the Daily Courant reported that the duke had arrived at Kassel on the Rhine, crossed the Main at Kostheim opposite Mainz, and then arrived at Darmstadt, all within a two-day period. ${ }^{21}$ On 6 June, the Post Man had him further on, passing the River Necker at Ladenberg, arriving at Eppingen and being expected soon at Heilbronn. ${ }^{22}$ Other military maneuvers and long sieges were reported in a similar style and were the very stuff of news coverage in an era of prolonged war.

The results of general elections was another kind of rolling story because results took so long to emerge from the process of counting votes. These stories were also prominent in the later Stuart press, given the frequent polling after the 1694 Triennial Act. Unlike modern British elections, voting occurred on different dates in different places (if it occurred at all-uncontested constituencies could declare their MPs much sooner than ones that had to organize ballots), so it took papers many issues to relay the nationwide picture. The coverage of the tumultuous 1710 election was typical. For some weeks before the first results, newspapers had been relaying candidacies and party mobilizations, but on 5 October they could finally start to list elected members from such early-declaring constituencies as Arundel, Buckingham, Chichester, Hertford, St. Albans, and Windsor. ${ }^{23}$ These announcements, however, were just the start of a long set. For the weeks through late November, when returns from Scotland began to dominate, papers carried an almost unbroken series of results. For instance, the Courant carried declarations every weekday from 5 October to 15 October. It broke the run the next day, but the 16 October issue did mention that the election in the City of London had been too disputed to conclude. The paper was back to reporting a substantial list of elections on 17 October. ${ }^{24}$ Even the results from one constituency could spread over time. Voting for some seats lasted more than a day, which, given that balloting was by public declaration, produced interim tallies that papers could print before the final result. This was the case in Southwark in 1710. The very paper that recorded the first national returns also reported that voting in the Surrey borough had started, but was incomplete, and noted the level of support that the candidates had received thus far. ${ }^{25}$ Here Woolf's idea of a fluid present seems particularly pertinent. Regularly appearing papers were able to report an emerging result. In constituencies where voting took days, they could even print a situation that changed as further votes-perhaps

${ }^{21}$ Daily Courant, 664, 1 June 1704. As is explained in the main text of this article, late Stuart newspapers had no headlines giving a title for individual items; all items were anonymous.

22 Post Man, 668, 6 June 1704.

${ }^{23}$ Among papers to carry results was Daily Courant, 2793, 5 October 1710; Daily Courant, 2794, 6 October 1710; Daily Courant, 2795, 7 October 1710; Evening Post, 180, 5-7 October 1710; London Gazette, 4753, 5-7 October 1710; Post Man, 1924, 5-7 October 1710.

${ }^{24}$ Daily Courant, 2793-2803, 5-17 October 1710.

${ }^{25}$ Daily Courant, 2793, 5 October 1710. 
even ones cast in reaction to the initial reporting-came in. Potentially, news might not only create a present but also alter it.

Less obvious for twenty-first-century readers used to instant reporting from around the globe, the practicalities of early modern journalism meant that even if an event were over in a day or less, the mechanisms of news production could ensure coverage over a much longer period. First, information could travel no quicker than speeding horsemen or ships with favorable winds could bring it. This meant that accidents of travel could delay lines of communication and so prolong the reporting season. If news was carried by more than one messenger, messages about a single event could reach London days apart, but papers would reopen the story if material that arrived later contained fresh details. Second, newspapers generally lacked direct European correspondents. Instead, they relied on translating the reports in Continental journals to cover foreign affairs. These overseas papersorgans such as the Leiden, Paris, or Amsterdam Gazettes - could give valuably different perspectives, which the English press was happy to reflect, but it could take different lengths of time for these other publications to print the news themselves and then for copies to be processed by London journalists.

A good example of a one-day event reported over time was Marlborough's famous victory at Blenheim in 1704 . The basic information about this reached London quickly, as the commander sent an express messenger, Colonel Parke, to Queen Anne with the core story. Parke brought all the facts he had had time to collate before leaving camp at seven on the evening of the battle, but this rapid departure did little to shorten the eight days it took him to reach Whitehall. The government ordered his news to be published immediately in an official broadside, and a brief summary of Parke's information appeared in the Daily Courant the next day, 11 August. ${ }^{26}$ A full account, however, emerged more slowly. On 12 August, the Courant expanded its coverage but clearly had not yet seen the initial broadside. It introduced its piece by recording that Parke's message "is said to be in the Main to this effect," but it did include details not contained in the official publication, which it may have received from reports of the messenger's informal briefings. ${ }^{27}$ This date, 12 August, also brought the thriceweekly papers their first chance to report the victory. The Post Man had seen the broadside and summarized it, supplementing it with information from letters from the royal court, where Parke was clearly expanding on his story. ${ }^{28}$

The next day revealed still further information in a second official broadside. This reproduced a full letter from Marlborough to the queen, sent by a second messenger on the morning after the battle. ${ }^{29}$ The slightly delayed dispatch meant the general had now had an opportunity to record more details, but it also meant his words did not arrive at court until three days after the initial report. The next day, 13 August, was a Sunday, so no newspapers appeared to advance the story, but over the next couple of weeks more and more facts about Blenheim unfolded. These appeared only gradually because they relied on intermediate publication or were

\footnotetext{
${ }^{26}$ This Afternoon Colonel Park [sic], Aid de Camp to His Grace the Duke of Marlborough (London, 10 August 1704); Daily Courant, 725, 11 August 1704.

${ }_{27}^{7}$ Daily Courant, 726, 12 August 1704.

${ }^{28}$ Post Man, 1306, 10-12 August 1704; 1309, 19-22 August 1704.

${ }^{29}$ The Lord Tunbridge Arrived Here this Evening, Being Sent by His Grace the Duke of Marlborough (Windsor, 13 August 1704).
} 
contained in letters that had taken witnesses time to write and get to London. On 15 August, the Daily Courant, the Flying Post, and the Post Man all reproduced Marlborough's letter about the battle to the States-General of the Netherlands, which had been printed in the Dutch papers a week before. Similarly, on 17 August, the Post Man printed a letter from a Dutch general to his political masters in Holland that carried a detailed account of the fighting from an English witness on 22 August. $^{30}$ Thus, delays in communication meant coverage of Blenheim spread over many days. White Kennett, the curate of St. Boltolph's, Aldgate commented on this, as he observed how the outcome of battle seemed better the more one steadily knew about it. In a thanksgiving sermon, he noted: "[W]e were not deceived or disappointed in the most early Informations given us ... fresher Reports have still brought the better News, and the Success proves every day greater and greater." 31

Late Stuart newspapers therefore encouraged a fluid sense of the present. By providing numerous updates and expansions of stories, they habituated readers to the idea that first impressions might alter and that reality might not be exactly as it had first seemed. In fact, the impossibility of swift travel meant this feature of reporting was even more prominent than in the twenty-first-century press. Yet for all this, other aspects of seventeenth- and eighteenth-century journalism confused this temporal sense, challenging some of the recent scholarship that has posited a "modern" sense of news-generated time. As we have just explored, the receipt and presentation of news around 1700 was not identical to the fully modern situation. This meant that the conception of the present could not be quite the same either.

We can start with the central difficulty in communicating over long distances. Among other effects, this disordered narrative and fragmented the present into a series of geographically separated constructions of contemporary time. To see this, it is worth examining how long it actually took to print the news from various locations. This is a question on which there seems to be surprisingly little systematic research. The approach taken here is to read all the stories in the Courant for June 1705 and June $1710 .^{32}$ This newspaper was chosen because it was a daily. Its news was therefore not delayed by a publication cycle-save the Sunday hiatus and some other exceptions explored below-but merely by slowness of communication. The months were picked more or less at random, but they came after the very first years of the Courant's history and so avoided any early immaturity in its newsgathering. These months also represent the summer campaigning season, during which time extensive warfare involving almost all the major European powers of the day ensured that stories were unfolding in widely separated parts of the world.

Reading the stories and counting the number of days between the reported date of events and the date of their publication reveals the following results. Occurrences in London most often appeared in print the day after they had happened. Events from elsewhere in Britain could take a little longer to report, usually depending on distance from the capital. So, for example, news of ship movements typically took two or three days from places in the southeast of England; they took four to six days from west or

${ }^{30}$ Post Man, 1307, 12-15 August 1704; Flying Post, [1448], 12-15 August 1704; Daily Courant, 728, 15 August 1704.

${ }^{31}$ White Kennett, A Sermon Preached in St Botolph, Aldgate, in London, on September VII (London, 1704), 14.

${ }^{32}$ Though see Woolf, "News, History," 84-86. 
north country ports and a bit longer from distant Scots harbors. A run of reports in the Daily Courant for 30 June 1705 illustrates the pattern nicely. ${ }^{33}$ Reporting from places overseas took longer and could scatter further from any norm because of the great uncertainty of maritime travel, but if all went well, the Courant could print news from Dutch towns in about five to seven days, from Dublin in about eight to ten days, and from Paris in around seven days to a fortnight. Moving out from cities to battlefields or away from northwest Europe naturally created longer delays. Clashes between French and English armies in Flanders and along the lower Rhine were usually reported within two weeks of their occurrence, although this could sometimes spread to nearly a month. Battles in northern Italy made it to the London press somewhere between twenty and thirty days later, while reports of maneuvers in Poland or the Baltic took about the same time. Dispatches from Spanish camps took between three and five weeks, mostly because the London papers got their freshest information via the Italian ports that supplied the anti-French war effort in the Iberian Peninsula. Meanwhile, the details of politics in Madrid, Naples, or Rome spent nearly a month in transit, tales of Habsburg intrigues took about the same time from Vienna, and updates from the Russian court in St. Petersburg never arrived in less than forty days.

The June Courants for our two years contained no news from beyond Europe. In fact, the absence of extra-Continental news is a notable feature of the press as a whole; this must question the geographical extent of any "contemporaneity." A sample of another month, September 1707, yielded only four stories from outside Continental Christendom in all the papers surviving in the British Library's Burney collection. Two were near duplicate reports of a naval skirmish near Antigua; the other two were updates on politics in Constantinople-which of course was technically, if not culturally, inside Europe. ${ }^{34}$ On those rare occasions when there was information from beyond the Continent, it took months. For example, the Flying Post for 8 August 1704 reported the arrival of ships from the West Indies, bringing news from across the colonies. By this route, readers heard of events in Virginia, Boston, New York, and across the Caribbean, but these had happened as long ago as April and May, a whole season earlier. ${ }^{35}$ Similarly, the Courant for 14 December 1703 had letters dated 17 September that described an attack on the Bahamas that had occurred in July, so this news took nearly half a year to arrive. While the Antigua battle we noted in 1707 was reported by one of the ships involved, it still took nine and a half weeks to get to London. Taken together, these long delays from anywhere outside northwest Europe demonstrate that the week it took to relay accounts of Blenheim via direct and express messenger were quite exceptional. While historians have rightly stressed the richness of the networks of communication that bound nations together in the early modern period, we must remember there had been no revolutionary advances in the speed of travel within the European continent since the classical period and that this was a significant barrier to the spread of news. ${ }^{36}$

\footnotetext{
${ }^{33}$ See, for example, the reports in Daily Courant, 1001, 30 June 1705.

${ }^{34}$ Post Man, 1827, 4 September 1707; Daily Courant, 1739, 11 September 1707; London Gazette, 4369, 22 September 1707; 1834, 23 September 1707.

${ }^{35}$ Flying Post, 1443, 5-8 August 1704.

${ }^{36}$ Work on European news networks can be traced in the bibliographies in Dooley, Dissemination of News, and Filippo de Vivo, Information and Communication in Venice (Oxford, 2007), 80-84.
} 
At one level, of course, these sorts of time lags must have added to the uncertainty and anticipation that we have been exploring as the modern, news-generated sense of the present. Yet in other ways, they moved the possibilities of understanding this new moment very far from later conceptions. Most crucially, readers were made aware that many of the events they were receiving as news had actually occurred a considerable time ago. This was guaranteed by the prominent dating on most reports. Items usually took the form of a dispatch, which began with the place and time of their writing. The passage of time was also underlined by the fact that by convention newspapers usually led with stories from abroad. In fact, they usually placed reports from the most distant places at the top of their first column, meaning that they led with their oldest material. Compounding this was the dominance of European over domestic stories in almost every issue. Foreign material typically comprised over 90 percent of reporting. The majority of "news" was therefore quite stale, and it was prominently acknowledged to be so.

It is true that calendrical differences made some events appear more current than they actually were. Before 1752, England used the Julian dating system, which by the 1690s had fallen ten days behind the Gregorian method used on most of the Continent and fell a further day behind in 1700. The dating gap between an occurrence on mainland Europe and its London publication therefore seemed less than it was in fact because papers headed reports from the Continent with the Gregorian date while printing the Julian one at the top of the whole publication. In effect, it took the English date a week and a few days to catch up with the European date: apparent time in which the news could travel without seeming to get older. Yet readers probably knew about this temporal illusion. In a world with considerable traffic between England and Europe, many folk would have been used to the dating differences, just as people today are used to time zone differences for electronic communication around the world. ${ }^{37}$ If late Stuart audiences ever forgot that two calendars were being used, they would be reminded when papers sometimes printed "n.s." after a date-for "new style," meaning the Gregorian system-or by the phenomenon of news from the near continent being reported in less than ten or eleven days, and so appearing to occur after the date of the paper which printed it. ${ }^{38}$ All this placed readers in an analogous position to astronomers, who know that to look outward through space is also to look back in time. If newspapers were constructing a new kind of present in the late Stuart era, this novel moment was actually divided into a series of different presents, separated spatially as well as temporally.

\footnotetext{
${ }^{37}$ It has become fashionable to stress England's European links in the late Stuart era. See Tony Claydon, Europe and the Making of England, 1660-1760 (Cambridge, 2007); Lisa Jardine, Going Dutch: How England Stole Holland's Glory (New York, 2008); Stephen Conway, Britain, Ireland, and Continental Europe in the Eighteenth Century (Oxford, 2011).

${ }^{38}$ Conventions on explaining dating systems varied: the Daily Courant tended not to help its readers by saying which it was using; the Post Boy almost always did; while other publications such as the London Gazette added "n.s." to about half its foreign reports, leaving people guessing about the system elsewhere, but aware there were alternatives. This phenomenon of postdating was particularly noticeable with the citations of foreign newspapers in which events were reported to have been reported. The Daily Courant, 980, 6 June 1705, had items from the Paris Letter dated 8 June; from the Brussels Gazette dated 9 June, which gave events themselves up to 7 June at the Flanders front; from the Leiden Gazette dated 11 June; from the Amsterdam Gazette dated 12 June; and from the Amsterdam Courant dated as late as 13 June.
} 
This matters because it questions some of the assumptions about a new progressive, fluid, and contemporaneous moment. Most obviously, the "present" for distant places must have had a character different from that for London in readers' minds. It would be much closer to fixed history in Woolf's spectrum of time because what was reported from places like Spain and Poland was now long past. ${ }^{39}$ Readers would be aware that even if they did not know what the consequences or sequels of the things they read about had been, much would have subsequently happened in the locations about which they were learning. There was therefore no chance that their actions might alter the flow of events, and in the distant locations themselves, the meaning of what had occurred would have become much clearer. The present was therefore philosophically different for distant places. It was less potentially flexible, and news of it was more like a historical tale, albeit one told in the style of Scheherazade, over days, as updates arrived. ${ }^{40}$

The time it took to get details from far-flung locations also meant that unfolding stories from different places could not be integrated into a coherent whole. There could not be one present narrative, but rather there was a shattered series of events, inevitably reported out of their true order. This disrupted any clear sense of contemporaneity and confused the development of stories with geographically dispersed elements. Take, for example, an issue of pressing importance to later Stuart readers: the progress of the anti-French alliances against the forces of Louis XIV in the wars of the League of Augsburg (1689-1697) and of the Spanish Succession (1702-1713). Because of the communication problems, newspapers could not really gauge the progress of the conflict or present any current state of play because variously delayed news was arriving well out of sequence.

One dramatic case illustrates how delay could reverse the pattern of events. It created an arguably false impression of an army-led British triumph, which became politically controversial as later reflection on what had actually happened allowed that first perception to be unpicked. The example takes us back to the battle of Blenheim, reported on 11 August 1704. Yet nine days before Marlborough's victory, Admiral Sir George Rooke had had as great a success, and arguably one with longer-term consequences, when his ships helped capture Gibraltar. Yet the news of this battle took twenty-one days to arrive in London and appear in papers, as opposed to Blenheim's nine, so information about Marlborough's actions overtook Rooke's. As a result, the admiral's triumph seemed something of a footnote to the conquest of the general, and it never achieved a moment of news dominance as Blenheim had. The first times Gibraltar appeared in the papers (14 and 15 August) it warranted a few lines, as compared to the whole columns of details that were by then being devoted to the Bavarian events. ${ }^{41}$

This mattered because of its political effect. Tories saw Rooke as more sympathetic to them than Marlborough, and they championed the navy as a less expensive, less corrupt, and less liberty-threatening military instrument than the army. Tories

\footnotetext{
${ }^{39}$ Woolf acknowledged this when talking about reactions to delayed reporting, "News, History," 83-84.

${ }^{40}$ The fact of delay is acknowledged in recent work on contemporaneity, but its psychological effect is only partly explored. The introduction to Dooley, Dissemination of News, dismisses the problem in a short section (3-5), though some of the essays themselves wrestle with it at greater length.

${ }^{41}$ See, for example, Flying Post, [1448], 12-15 August 1704; Post Man, 1307, 12-15 August 1704; Daily Courant, 727-28, 14-15 August 1704.
} 
therefore demanded that Rooke's achievement receive its full recognition. They published pamphlets and poems to glorify the capture of Gibraltar, so attempting to counter Whig charges that this success was of little strategic importance and to distract the public from Marlborough's growing celebrity. ${ }^{42}$ In this, the Tories were tacitly appealing to the actual order of events over the sentiments created by the distorted ordering in newspapers. They were reminding people that there had been an early naval victory, which might have received celebration for a week before Blenheim and that could have been seen as the first significant blow against the enemy, if only people in England had known about it sooner. Here, reality and reporting had created differing narratives, shattering any agreed sense of the development of the story and rendering the whole tale partisan.

If travel delays created fractured "presents" in the press, a key practice of late Stuart journalism bent its construction of time even further away from our contemporary experience of news. This was the papers' cataloging approach to reports. Early modern journalists printed the information they received far more systematically and with far less editorial intervention than twentieth-first-century ones. For overseas news in particular, they rarely claimed to do more than translate, transcribe, and reprint items of dry fact that had appeared in foreign journals as they were received. This could lead newspaper publishers, for example, to reproduce pro-French sources exactly, and so to speak of the troops of the English-led confederacy as "The Enemy." 43 It also meant that newspapers sometimes had to remind readers that faithful reproduction was all they did. At one point in 1705, the Daily Courant practically ceased relaying news for two issues to defend itself against accusations that it had falsely reported a great naval disaster for Queen Anne's allies. It had, it said, simply recounted what the Paris Letter had printed, but it had assumed its readers would not give much credence to the story because of that journal's obvious proFrench bias and its poor reputation for accuracy. ${ }^{44}$

This lack of any mission to comment upon, or to explain, the news may have stemmed from a lack of editorial resources. It may also have arisen from a fear that excessive intervention in the presentation of information would lead to accusations of bias in a medium that was trying to build its reputation through objectivity. ${ }^{45}$ The Daily Courant's first copy boasted of its complete lack of prejudice, and within a few issues it had elaborated on its manifesto to include the claim that the "proper and only business of a news writer ... [is] delivering the facts as they are related." 46 Whatever its cause, simple cataloging was the overwhelmingly predominant style of the later Stuart news industry. We see the papers of the period being more cautious about interfering with raw reports, not only than the press of the later eighteenth century, but even than their precursors in the 1640s. This had notable consequences for the presentation of time.

${ }^{42}$ A Narrative of Sir George Rooke's Late Voyage to the Mediterranean, where he Commanded as Admiral of the Confederate Fleet [London, 1704]; Reflections on the Management of Sir George Rooke Knight (London, 1704); William Pittis, A Hymn to Neptune (London, 1705).

${ }^{43}$ See, for example, the lead story in the Daily Courant, 2688, 5 June 1710.

${ }^{44}$ Daily Courant, 999-1000, 28-29 June 1705.

${ }^{45}$ Nicholas Brownless, "Narrating Contemporaneity: Text and Structure in English News," in Dooley, Dissemination of News, 225-50, esp. 236-40, suggests earlier Stuart news-sheets had deliberately done little with reports to avoid accusations of bias, and the motive may well have been the same in the later period.

${ }^{46}$ Daily Courant, 1, 11 March 1702; 10, 30 April 1702. 
The first effect of editorial caution was to make news hard to follow. Journalistic practice meant that reports popped up when papers got the relevant information and were reproduced with no real exposition. To get much out of such items, readers would need a head for a large number of parallel stories, some of which might not have been mentioned for some time and some of which might never have been covered before. In particular, anyone trying to follow the complex European wars and diplomacy that filled the journals during Queen Anne's reign would have needed detailed background information. Readers would require extensive geographical knowledge of the cities and fortresses on the various fronts (and the papers provided no maps to help) and encyclopedic recall of the names and roles of generals, ambassadors, courtiers, and minor sovereigns. They would also need a good sense of the allegiance of the original writer of items to determine whether phrases such as "their armies" meant the forces of England's friends or enemies. What, we might wonder, would someone have made of a report such as this?

Leghorne: May 24. On Tuesday last arriv'd here 3 Ships from Barcelona in 9 days, and their Companies report, that the Army of the Allies consisting of above 20000 Men was on the March towards Terragona; that they had an Account of the Duke de Noailles being in Morion with the French troops in Roussillon, in order to make an Irruption in Catalonia but that divers Precautions were taken to oppose it. The Duke of Tursis sailed hence on Tuesday last with 6 of his Galleys for Porto-Longone where ... 3500 Men of regular Troops commanded by the Duke of Vedarjas are to be put on board them. 'Tis given out that they are designed against Sardinia, where the Partisans of the two Crowns pretend still to have Intelligence; but tis rather believed the Design is against Piombiao. ${ }^{47}$

Such a barrage of unmediated fact required expertise to understand, which would disrupt any coherent sense of time if audiences lacked this essential knowledge. To fit events into an unfolding narrative, people needed a context and some sense of the broad outlines of the story so far. Failing to provide this, newspapers would often have left nothing but disjointed news data, which might have been hard to fit into any temporal pattern at all.

Yet if the "catalogic" approach could confuse on some occasions, on others it might move news away from the fluidity of a modern present, toward the more traditional fixity of history. This was a result of the one technique that newspapers did use to organize their material. Although journalists made no attempt to meld different accounts of a set of developments into a single item, they did at least place the reports in chronological order when they had several from a particular theater. This produced something like a complete story, especially since the papers did not edit down the earlier reports, apparently assuming that readers would not lose interest in older stuff even if it had been superseded by later information. What the papers printed, therefore, was a series of items in time sequence. These could all appear on the same day, even though the original events might have taken quite a period to unfold. This looked more like historical rather than modern journalistic coverage, and it tended to resolve stories, removing that sense of uncertainty that is supposed to characterize a progressive present.

${ }^{47}$ Daily Courant, 2690, 7 June 1710. 
Delays in communication were a common reason that newspapers presented their material in this chronicle-like fashion. If, for instance, boats could not sail from the Low Countries, news might effectively pile up in Dutch or Flemish ports. When vessels finally set off, reports from different stages of a story would pour in together and be printed as a complete narrative. An example-one that shows quite how strange, for a twenty-first-century reader, the presentation of news could be-comes from the 1710 fall of Douai to Marlborough's forces. This occurred on 29 June (Gregorian style, 18 June Julian), but it had been preceded by a ten-day battle over the outward fortifications and negotiations over the precise terms of surrender. We might expect this to have been followed day by day in London newspapers. The early parts of the narrative were, but at a vital moment, the mail was delayed. There appear to have been no fresh foreign papers received between 14 and 19 June. The morning after the hiatus, a relieved Courant announced, "[Y] esterday the mails arrived from Flanders," which meant that the story rushed forward when the post finally came. ${ }^{48}$ The 20 June issue of the Courant carried reports from Douai dating from 20 and 21 June (Gregorian) relating the start of the attack on the city, yet it followed this immediately with a report of 24 June announcing that the fighting had been tough but that the allies had now made a sufficiently large breach in the walls that a final attack was imminent. The paper then went on to report ship movements in Portsmouth and Falmouth, so this looked like a still unconcluded story, except that the journal then finished, as it always did, with the London news. And the key event reported for the capital was the arrival in the city of a Colonel Panton, almost certainly on the same sailing of boats over the Channel as the posts. He had carried with him the message that Douai had capitulated. To modern eyes, the paper therefore seemed to render its first items redundant.

The structure of this news in other papers appearing on 20 June was similar, and the printing of complete stories was immediately repeated. ${ }^{49}$ After 19 June, the mail was again suspended for over a week. On 27 June, the Gazette wailed that four successive posts from Holland had been delayed. To cope, papers printed Panton's message in full, cannibalized the foreign journals that had arrived on 19 June for news from places aside from Douai, and then were forced to use lengthy proceedings of the Irish Parliament to fill their columns. ${ }^{50}$ On 29 June, however, the Courant announced that the mail had finally arrived from Ostend and Holland. The paper was now able to reproduce correspondence from Douai, dating from 26 June to 3 July (Gregorian). ${ }^{51}$ This took up the town's story on several stages by reporting arrangements after its fall, and the Gazette and Post Boy presented a similar forward rush of information when they appeared the day after. ${ }^{52}$

${ }^{48}$ Daily Courant, 2701, 20 June 1710. The gap can be deduced not only from the Courant's comment but also by the fact that papers printed after 15 June quoted no Continental journals of a date later than those available on that day until 20 June.

${ }^{49}$ London Gazette, 4706, 17-20 June 1710; Post Boy, 2356, 17-20 June 1710; Post Man, 1899, 17-20 June 1705.

${ }^{50}$ Daily Courant, 2702-9, 21-28 June 1710; London Gazette, 4707-9, 20-27 June 1710; Post Boy, 2357-58, 20-24 June 1710; Post Man, 1892, 24-27 June 1710.

${ }^{51}$ Daily Courant, 2712, 29 June 1710.

${ }^{52}$ London Gazette, 4710, 27-29 June 1710; Post Boy, 2630, 27-29 June 1710. 
The tendency to produce completed narrative was further compounded by the fixed physical format of late Stuart papers. Adhering to the model pioneered by the Gazette in the 1660s, all were composed of a single sheet, printed in two columns on both sides. Given that editors wished to make money with advertisements, which therefore filled much of the back page, this left limited room for news and forbade expansion when information crowded in on print rooms. Papers coped by holding over some stories to later issues, but of course by the time those later editions came out, their writers might have received more up-to-date accounts. Given their cataloging approach to reports, this resulted in a string of items outlining the development of stories over a period of time, rather than slowly emerging news. Moreover, journalists had a "critical mass" approach to reporting. Quite frequently, they held back items from a particular part of the world until they had a large enough store to make a sustained feature on developments in that theater, or at least until a slow news day demanded a quantity of saved material to pad out the issue. Examples of such practices from the Daily Courant include the batch of reports from Vienna on 7 June 1705, which transcribed stories from Dutch newspapers dated from 2 to 13 June (Gregorian) and covered a string of events in the Hapsburg capital ranging from 29 April to 30 May (again Gregorian). ${ }^{53}$ They also include a rush of news from Spain in the issue for 30 June 1710. That day the Courant updated its audience on Iberian events for the whole first half of the month, following the suspensions in Channel sailings analyzed in the preceding paragraphs and after a further delay caused by reserving space in the 29 May number for the news pouring in from Douai. ${ }^{54}$

This style of reporting was not creating the uncertain and emerging present we are exploring, but looks far more like settled history. It was also far from the modern journalists' "inverted pyramid," in which stories are structured to begin with the most important facts, rather than the ones which happened first, and was different again from the stress on "breaking" news found in twenty-first-century news media. In fact, there were ways here in which the practices of Queen Anne's reign were further from modern standards than the much earlier journalism of the Civil War. The newsbooks of the 1640s were more unlike today's newspapers than later Stuart examples in terms of format and frequency of publication but closer to twenty-first-century newspapers in that they provide a "lead" in a story, as Nicholas Brownlees has found. Early seventeenth-century news reporting summarized the most important events in the first sentences, even if this disturbed the chronological flow. Some 1640s newsbooks also helped the reader with marginal captions that acted like headlines. ${ }^{55}$ Editors under William and Anne abandoned these devices and so forced readers to plow through a chronological narrative to find the denouement.

So far, we have been examining how the practicalities and practices of journalism sometimes fragmented any sense of contemporaneity and pushed reporting to resemble fixed history rather than an evolving present. Another effect was, in a sense, to freeze time. Late Stuart newspapers often drew attention to the hiatus in narrative when they could get no new information. Because they had to appear

${ }^{53}$ Daily Courant, 981, 7 June 1705.

${ }^{54}$ Daily Courant, 2713, 30 June 1710.

${ }^{55}$ Brownless, "Narrating Contemporaneity," 240. 
again in a few days or even on the morrow, papers frequently apologized that there was nothing to report, for example, when complaining that mail boats had not arrived from the Continent or of stasis on slow-moving military fronts. ${ }^{56}$ The news was thus that there was no news. This was a consequence of a press with a more modern publishing schedule, but it was not a step toward a modernity defined by constant update.

A fine example of this temporal freezing came in November 1703. In that month, the "Great Storm," probably the most violent hurricane to affect the southeast of England in historical times, wrought a trail of devastation to towns, woods, and shipping. ${ }^{57}$ Damage in London was reported rapidly, but the effects in more distant places took time to come in, creating agonizing lags. This was particularly true with ships of the Royal Navy that were blown off their anchorage. They disappeared from shore, but no one knew what had happened to them until they could sail back home. The case of the gloriously named Admiral Sir Cloudesley Shovell gripped the nation precisely because of this ignorance. At the start of the tempest on 27 November, the admiral had been anchored at Gunfleet in the Thames estuary. He survived the storm by cutting his main mast, but it took him so long to get back to where he could report his fate that a terrifying pause developed in the newspaper coverage.

The first note of concern for Admiral Shovell was expressed by an item in the Daily Courant on 29 November. The report contained a list of damaged and lost ships, writing, "Pray God preserve Sir Cloudsly Shovell," and indicating that he had set sail from Deal for the Thames just before the hurricane. ${ }^{58}$ Over the next days, papers covered the Shovell story mostly by admitting what they did not know. On Tuesday 30 November, the Post Man said the ships that had left Deal before the storm must now be so dispersed that it would be impossible to say what had happened to them. ${ }^{59}$ On the same day, the Daily Courant observed that there was no news of the admiral. This remained the paper's position for the rest of the week. ${ }^{60}$ From Wednesday to Friday (1 December to 3 December), various papers reported "no news yet," "no advice," and "no word" of the admiral.61 On Friday, the Courant suggested that a man recently arrived in London had seen Shovell's ship after the storm sheltering at Long Sand Head, but on Saturday it had "no certain advice," and 5 December was a Sunday, so no newspapers appeared. ${ }^{62}$ As a result, it was not until 6 December that papers could confirm the survival story. The Courant reported that Admiral Shovell had arrived back at Gunfleet the previous Thursday, while the Gazette went one better, printing Shovell's own account of his ordeal, which had arrived at the admiralty in Whitehall on the Sabbath. ${ }^{63}$

\footnotetext{
${ }^{56}$ See above, notes $49-52$, for reports of postal delays. For one military void, see "There is no considerable news from the frontier [in Spain]," Daily Courant, 995, 23 June 1705.

${ }^{57}$ Martin Brayne, The Greatest Storm: Britain's Night of Destruction, November 1703 (Stoud, 2002), provides the key facts.

${ }^{58}$ Daily Courant, 405, 29 November 1703.

${ }^{59}$ Post Man, 1213, 27-30 November 1703.

${ }^{60}$ Daily Courant, 406, 30 November 1703.

${ }^{61}$ Daily Courant, 407, 1 December 1703; Daily Courant, 408, 2 December 1703; Post Man, 1214, 30 November-2 December 1703.

${ }^{62}$ Daily Courant, 409, 3 December 1703; Daily Courant, 410, 4 December 1703.

${ }^{63}$ Daily Courant, 411, 6 December 1703; London Gazette, 3972, 2-6 December 1703.
} 
In many ways, the 1703 storm confirms the lesson of Blenheim. Problems with communication had spread a single event over days of coverage. It thus spun an evolving story out of a single incident and so extended the present. In addition, gaps in reports created the psychological tension of uncertainty, another key part of Woolf's analysis. Bereft of concrete information, readers knew the situation must be developing, but they did not know how. This unease must have been compounded by the rumor and speculation we are about to describe. Yet the storm also illustrated how journalists stressed the stop in the story. For several days, they emphasized that they had no fresh information. Certainly papers tried to compensate by theorizing about Shovell's fate, but these efforts slowed time even further by underlining that there was no concrete news and by sparking a journalistic caution that actually delayed the story's happy end.

Thus papers admitted they had thin evidence even as they wondered what had happened to the admiral. On 1 December, the English Post reported that ships that had been with Shovell had been ordered to cut loose from their anchors. This led the paper to believe that the great seaman would have done the same and so might have blown to Holland, but it said there was no way to know this because the wind still prevented travel from the Netherlands. ${ }^{64}$ Similarly, on 2 December, the London Gazette supposed that the admiral must have been blown far to the northeast - in fact, a ship in his fleet had been swept all the way to Scandinavia, although nobody knew this at the time- and this would be why no one knew where he was. ${ }^{65}$ If speculation underlined the admissions of ignorance, so did false news and the fear of spreading it. On 30 December, the Post Man said that a report had arrived in London suggesting that Shovell had returned to anchorage off the Kent coast. ${ }^{66}$ This, however, was wrong, and it provoked a skepticism that further delayed accurate reporting. The Daily Courant concluded its coverage of the first true poststorm sighting of Shovell with, "What Truth there is in this Man's Report, Time will shew." The paper only strengthened this a little the next day to say that the witness "was very certain." 67 At the same time, the Post Man atoned for its earlier error by observing that the various stories it had heard circulating in London about Shovell were all too unreliable to print, even though at least one of them turned out to be correct. ${ }^{68}$ Here, the press reaction was very far from the wholesale speculation that has been analyzed by Will Slauter as a central feature of late eighteenth-century gazettes, which he saw hurrying the time-sense of audiences forward. ${ }^{69}$ Later Stuart papers wished to stress they had no certain updates to relay, and they were easily frightened into waiting for absolutely confirmed reports.

Such stopping of narrative also resulted, paradoxically, from the papers' interest in the future. Sometimes the journals reported things that were going to take place at some point hence. We would expect audiences to want to read about planned or predicatable events, and this might even have encouraged that progressive anticipation

${ }^{64}$ English Post, 300, 29 November-2 December 1703.

${ }^{65}$ London Gazette, 3971, 29 November-2 December 1703.

${ }^{66}$ Post Man, 1213, 27-30 November 1703.

${ }^{67}$ Daily Courant, 409, 3 December 1703; Daily Courant, 410, 4 December 1703.

${ }^{68}$ Post Man, 1215, 2-4 December 1703.

${ }^{69}$ Will Slauter, "Forward-Looking Statements: News and Speculation in the Age of the American Revolution," Journal of Modern History 81, no. 4 (December 2009): 759-92. 
that might be at the heart of a modern present. Yet sometimes things played out rather differently. On occasions, the very fact that reports were about the future could freeze news. Because the events in question had not yet happened, nothing new could be said about them, but papers might nevertheless dwell on the subject, repeating items word for word for days at a time. Good examples in this highly politicized age were notices of election polls or of meetings to select or support candidates. The sort of parliamentary results coverage we described earlier was interspersed by news that voting would occur on particular days, that someone had been nominated, or that citizens in a particular constituency were going to rally. These reports were clearly aimed at boosting support for particular candidates and so behaved more like advertisements. Indeed, the pieces were probably supplied by candidates themselves. Such notices appeared at the end of the news section, just above the classified notices. Advertising, of course, works best with repetition, so identical items appeared over and over again. The Daily Courant, for example, informed its readers that Sir George Stanhope would be standing at the forthcoming Middlesex poll on 13, 14, 15, 16, 19, 21, and 23 September 1710. It then began obsessing about the City of London election, repeating the announcement of the ultimately doomed candidacy of four Whigs on 26, 27, 28, 29, and 30 September. That story was also repeated by the Post Man on 26 and 30 September. ${ }^{70}$ Here, the fact that the "news" was about the future meant it did not, and could not, move on.

Anticipation could thus stop time, but it could have other effects. One common variety of future writing, which underlines some of the questions we have been raising about the press's role in creating any modern present, was the case of stories from abroad in which correspondents reported not only what had just happened in their part of Europe but also what local people were expecting to happen next. This was common in accounts of the various contemporary wars: once an army had gathered at a fortress, for instance, it was expected to attack in the next few days. In examples from June 1705 and June 1710, the press did come closer to the later eighteenth-century practice of open guessing about the future that Slauter describedalthough under Queen Anne speculation tended to be about the immediate aftermath of local events rather than more wide-ranging geopolitical developments that were anticipated in the later age. In one example, the Courant reported on 11 June 1705 that Huy had just fallen to French and Bavarian troops. It was therefore expected that the armies would move off smartly to their next target, Liege. ${ }^{71}$

Of course, newspapers printed this sort of speculation to try to bridge that gap between the news they had from distant places and the time it was read. If the latest firm reports were weeks old, it helped a little to know what people on the ground thought was likely to happen in the "unknown" period since the words had been written. But this created a greater complexity in time perception-a rare type of complexity for twenty-first-century audiences for whom the temporal gap rarely opens. Effectively, the papers were talking in a compound tense, the "futurein-the-past." The content of this tense was speculative because writers could not say if things had turned out the way that had been predicted, but it was not speculative

${ }^{70}$ Daily Courant, 2774-77, 13-16 September 1710; 2779, 19 September 1710; 2781, 21 September 1710; 2783, 23 September 1710; 2785-89, 26-30 September 1710; Post Man, 1920, 26-28 September; 1922, 30 September-3 October 1710.

${ }^{71}$ Daily Courant, 983, 11 June 1705. 
in the same way as coverage of Shovell's Great Storm experience. For the future-in-thepast, speculation was about what had happened some period ago, not what was happening now, and readers would realize that many people geographically closer to events would already know the outcome. Consequently, the future-in-the-past was uncertain, but it was not as philosophically fluid as the unknown present. Indeed, the catalogic approach to reporting meant that any uncertainty could be both created and resolved in the same issue. Speculation might occur, but then be instantly confirmed or refuted. The Courant for 20 June 1705, for example, carried a story dated 17 June (Gregorian) that the elector of Bavaria was planning to besiege Liege-where he had indeed gone after the fall of Huy - but that he was waiting for his artillery to arrive. Yet the very next item was correspondence dated 20 June, saying the town gates had been forced by the Bavarians forty-eight hours earlier. This was not quite the pattern of events advertised a few lines before, and it instantly falsified the earlier prediction. ${ }^{72}$ This last example encapsulates some of the most profound differences between modern journalism and the presentation of news in the late Stuart press, and it allows us to move toward a conclusion.

What does this survey of the later Stuart press suggest about its audience's perception of time? In many ways, it has confirmed the theories with which we started. There have been numerous examples of newspapers creating progressive expectation-reporting incomplete news and so creating a space between fixed history and unknowable future. We have also seen newspapers recording events from a wide geographical area and thus expanding the sense of what was happening "now." The continuous vigor of the press after 1695 ensured that these presentations of time became a regular part of their readers' lives and were not confined to moments of uncensored crisis. Moreover, features of later Stuart news, particularly the delay in relaying information, made the characteristics we have been examining more prominent than they are today.

However, other features of the press were unlikely to produce the kind of present that has been posited. Most noticeably, the prominent signposting of the age of stories, combined with communication delays and the journalists' approach to arranging items, often resulted in a chronicle rather than in an evolving present moment. Stories frequently unfolded in their entirety, with any uncertainty created by the first items in a run rapidly resolved. This calls into question the idea of a divorce between a news-created present and history. Woolf may have been right that news media no longer used the word "history" to describe its coverage of recent events, but the papers often came close to the sort of finished accounts we expect from that genre of writing. ${ }^{73}$ This caveat is underlined by how newspapers were used in the later Stuart era. We know that at least some readers kept runs of old papers because this is how some complete collections have come down to us. ${ }^{74}$ Other readers copied snippets of information from printed journals into their diaries to incorporate into

${ }^{72}$ Daily Courant, 992, 20 June 1705.

${ }^{73}$ Woolf, "News, History," 84, 98-100.

${ }^{74}$ Charles Burney's newspaper collection, at the heart of the British Library's holdings, grew around the journals found in his aunts' coffeehouse: Lars Troide, "Burney, Charles (1757-1817)," Oxford Dictionary of National Biography, 60 vols. (Oxford, 2004), 8:952-54. 
their personal histories. ${ }^{75}$ Still others, such as Roger Morrice or Narcissus Luttrell, gathered news - often gleaned from the papers-in huge dated manuscript compendia. The purpose of such accumulations can be opaque to modern scholars, but they look like archives of completed events intended for later historical reference. ${ }^{76}$ This suggests that at least some audiences shared the journalists' "catalogic" approach and saw newspapers as a record of a known past, not as disposable constituents of a changing present.

Moreover, while the papers look like old-style chronicles, they sometimes demanded understandings of time that could be more complex than any new "present." The interpretations with which we started this article tended to assume that the Stuart age saw a move to a novel, but nevertheless fairly clear, sense of time. Although it involved some uncertainty because of its focus on a rapidly evolving current moment, the new definition of present time was taken to have fairly easily definable characteristics-it was progressive, fluid, contemporaneous, and "empty" - and it was thought to have displaced other ways of conceptualizing chronology. Yet the newspapers contained a far larger variety of types of time than this. Journalists did encourage a modern idea of the present, but they also constructed history, froze time, and reversed the order of occurrences. We see them dealing in multiple timelines, engaging in self-conscious speculation about two kinds of future (that in the future and that in the past), and presenting events in so contextless a manner that it was difficult to construct any clear chronology. We might believe that this left readers confused about how to understand the news. They were being presented with a complex, multilayered, and fragmented picture, with no logical narrative or hierarchy of significance and with many different versions of time playing simultaneously.

There is strong circumstantial evidence for such confusion. Historians, including Woolf, have uncovered considerable contemporary anxiety about an indigestible barrage of information. This anxiety fed the general concern about the truth status of printed material that Mark Knights has explored for later Stuart England. ${ }^{77}$ Moreover, other genres of media emerged alongside papers to make sense of the data the news journals provided. We have already mentioned that Queen Anne's reign was a golden age of sermonizing and pamphleteering. Both media took the raw data of recently reported occurrences and wove them into more structured interpretations of the world. In addition, another kind of print periodical arose after 1695. Works including The Review (written by Daniel Defoe from 1704 to 1713), The Examiner (written by Jonathan Swift from 1710 to 1711), The Observator, The Tatler, and The View of the Times were similar to papers in that they were news-centered and appeared regularly and relatively cheaply, but different in that they concentrated on commentary rather than on reporting. All these genres were popular. They may well have been

\footnotetext{
75 Woolf, "News, History," 99.
}

${ }^{76}$ The Entring Book of Roger Morrice, 1:98-116, has remarks on the unclear purpose of the work. Narcissus Luttrell, A Brief Relation of Affairs of State from September 1678 to April 1714, 5 vols. (Oxford, 1857). For other news gatherers, see Mark Knights, "Judging Partisan News and the Language of Interest," in Fear, Exclusion and Revolution: Roger Morrice and Britain in the 1680s, ed. Jason McElligott (Aldershot, 2006), 213-15.

77 Woolf, "News, History," 86-87; Knights, "Judging Partisan News," 205; Knights, Representation and Misrepresentation, part 2. 
so because they brought order and meaning to material that papers had disorganized into multiple time streams.

There are two historiographic ironies here. First, when the other forms of print utilized the papers' news, they fitted it into temporal patterns very far from any modern "present." The sermons, pamphlets, and non-news periodicals of the later Stuart period incorporated events into highly partisan views of the world that assumed some very deep-seated, and so unchanging political realities. For example, fast sermons for the wars against France took details of the struggle and interpreted them as evidence of the constant, satanic wickedness of Louis XIV. This, they asserted, had been clear in all its essentials from the start of his rule back in the 1660s and was inevitable from the centuries-long anti-Christian corruption of his Catholic faith. ${ }^{78}$ Indeed, the generic sermon form based on the exposition of a biblical text assumed there were direct analogies between the experience of long-dead Hebrews and contemporary audiences. This suggested that little ever changed. Meanwhile, Whig pamphlets urging vigorous prosecution of the war used similarly static models. For instance, they cited decades of French perfidy to warn against the moves for peace made after 1710; some pamphlets were little more than litanies of endlessly repeated treachery, designed to establish the unfaltering danger of the enemy. ${ }^{79}$ Similarly, in the last years of Queen Anne, the Tory press used political, diplomatic, and military developments to prove the existence of a long-standing plot to advance the interests of Whigs and war-profiteers. This plot, pamphlets and periodicals asserted, had been originated twenty years before and had been consistently prosecuted ever since. ${ }^{80}$ Tory rhetoric stressed the constancy of the evil, but the polemic itself had hardly changed since its early incarnation in Charles Davenant's "Tom Double" pamphlets, published at the turn of the century. Over a decade of military, political, and diplomatic news made hardly any difference. ${ }^{81}$ In this sort of writing there was no progressive and evolving present. Instead, events were merely the latest instances of unaltered, almost eternal, archetypes. Regular papers were spawning an incomprehensible babble of information, which then had to be disciplined in other forums, and people seem to have found the facts easiest to master when characterized by decidedly premodern and essentially timeless tropes. They used notions such as persistent conspiracy, or the unending struggle against the Antichrist.

The second irony takes us into more speculative territory. The newspapers' new present is supposed to be modern, yet they often presented a time that was fissured, multispeed, speculative, and narrative-less (or, at least, with a confused narrative). If we look for later comparisons, this appears less like the ordered and edited chronological sense of high twentieth-century newspapers and more like the highly diverse and complex perceptions of time generated by the new and multiple media of the last

78 Tony Claydon, William III and the Godly Revolution (Cambridge, 1996), 134-47; Claydon, Europe, 158-92, 197-98.

${ }^{79}$ See the works cited in Claydon, Europe, 198, n. 245-46, esp. A Clear View of the French King's Bona Fide (London, 1711).

${ }^{80}$ This was the refrain of most pro-peace rhetoric: to take Jonathan Swift's work alone, see The Conduct of the Allies (London, 1711); and The Examiner especially references to twenty years of abuse as at 14, 9 November 1710; 18, 7 December 1710.

${ }^{81}$ The rhetoric leant heavily on Charles Davenant, The True Picture of a Modern Whig (1700), which introduced the Tom Double character as the chief conspirator. 
few decades. This has been conceptualized not as a "modern" but as a "postmodern" experience. According to postmodernist analysis (and in what follows I offer my own concise synthesis of a diverse and sometimes contradictory movement), the last few decades have been characterized by chronological fracture. In this view, the old "grand narratives" that used to structure our sense of the human story-notions such as steady political emancipation and the advance of scientific knowledgehave collapsed. Society has thus entered a state of "posthistory", in which the past can no longer provide coherent explanations of our situation today because there is no meaningful pattern of development within it. This has left people trapped in the present. Yet the present itself has fragmented. The hugely varied range of discourses available through multiple sources of information and opinion cannot agree what the present is because each of them has a different account of time's operation and of the length of each significant moment. For example, computing and cosmology have very different measures of time (nanoseconds versus billions of years), and neither is close to the temporal range of the vast variety of human interactions, which themselves run to multiple rhythms. As one commentator has put it, we are today confronted with "the co-existence of radically different timescales ... scattered across temporal universes that can no longer be reconciled." 82 In such a world people lose chronological bearings. They find it hard to construct identities because there is no sense of history in which these can be rooted, and they are faced with the disorientation and ambiguity that are the hallmarks of postmodernism more generally. ${ }^{83}$

Of course, not everyone would accept this description of twenty-first-century society. More pertinently, the preconditions of this postmodernist world are very far from the situation in later Stuart England. Queen Anne's subjects were not faced with instant electronic communication, knowledge of the vast age of the universe, or crises of grand narrative. Yet the need to cope with radically different notions of time may still have had thought-provoking parallels among readers of later Stuart newspapers. Obviously it is difficult to know how news time was experienced in past centuries. We have no record of what went on in people's heads as they read the papers, and any written responses to news in letters, diaries, or marginalia are both removed enough from that internal mental state and sufficiently scattered to question their typicality. Yet the fragmented presentation of time in Stuart era journalism would seem to have demanded a struggle to construct a coherent temporal sense. It suggests we might experiment with "postmodern" models in future research. For example, one account of the disrupted chronological structure of "postmodern" novels stresses many features we have just seen in later Stuart newspapers. These include repetitions that freeze and confuse time; dizzyingly rapid switches between timelines, forcing the reader to flip through disjointed texts to follow particular stories; and a verbatim incorporation of other sources into narratives that

\footnotetext{
${ }^{82}$ Ursula K. Heise, Chronoschisms: Time, Narrative, and Postmodernism (Cambridge, 1997), 6-7.

${ }^{83}$ The notion of a collapse of grand narrative was advanced in Jean-Francois Lyotard, La Condition Postmoderne: Rapport sur le Savoir (Paris, 1979). The sense of the loss of history was classically stated in Fredric Jameson, "Postmodernism and Consumer Society," in The Anti-aesthetic: Essays in Post Modern Culture, ed. Hal Foster (Port Townsend, WA, 1983), 111-25. Comment on the fragmentation of time this has produced can be found in Heise, Chronoschisms, esp. part 1; Hans Bertens, The Idea of the Postmodern: A History (London, 1995), 163-64.
} 
blurs the time point of the writing. ${ }^{84}$ There may be lessons in how readers react to such writing. If learning from such literary criticism may be too abstract for historians, recent research in new media studies may have more concrete parallels. For example, the late Stuart papers' catalogic approach to items resonates with electronic blogs where old contributions remain posted even once superseded by later material. ${ }^{85}$ Again, the first newspapers' reliance on unmediated stories from other sources has parallels in contemporary "citizen reporting" via mobile phone cameras and eyewitness texting. ${ }^{86}$ Both these phenomenon disrupt editorial management (including the chronological scripting) of what is important in the news, and they perhaps take us back to the later Stuart situation where unpyramided stories left readers to pick their own way through reports.

Yet whatever the value of postmodernist analysis in this field, the basic point remains. In what is, in the end, a modest historical piece about journalism in the age of William and Anne, I hope to have shown the complexity of time-sense in the first regular and sustained newspapers. These could certainly construct something like a modern "present." But that was neither their only nor necessarily their most prominent presentation of time.

${ }^{84}$ Heise, Chronoschisms, 55-68.

${ }^{85}$ For thoughts on narrative structure in blogs and other new media forms, see Ruth Page and Bronwen Thomas, eds., New Narratives: Stories and Storytelling in the Digital Age (Lincoln, NE, 2011).

${ }^{86}$ For analysis of the effects of citizen reporting on live television news, see Stephanie Marriott, Live Television: Time, Space and the Broadcast Event (London, 2007), chap.7. 